\title{
ALKALINE TRANSESTERIFICATION OF SUNFLOWER OIL TRIGLYCERIDES BY BUTANOL-1 OVER POTASSIUM HYDROXIDE AND ALKOXIDES CATALYSTS
}

\author{
V.P. Kukhar Institute of Bioorganic Chemistry and Petrochemistry of the National Academy of Sciences \\ of Ukraine, Kyiv, Ukraine
}

\begin{abstract}
Butyl esters of fatty acids are used in engineering and are considered as potential biodiesel fuel. The difficulty of separation of products, obtaining by alkaline transesterification of oils, causes the pure attention of researchers to this one-stage of synthesis of butyl esters. The difficulty of separating the products obtained by alkaline transesterification of vegetable oils leads to the limited attention of researchers to this one-step route of the synthesis of butyl esters. The aim of this work was to compare the characteristics of the alkaline transesterification of sunflower oil on hydroxide and water-free alkoxide catalysts and to interpret the observed features from the point of view of reaction mechanism. Transesterification was carried out at the temperature of 20 and $40^{\circ} \mathrm{C}$ using potassium butoxide, methoxide and hydroxide. The highest equilibrium yield of butyl esters (up to 96\%) was achieved when potassium butoxide was used, whereas it did not exceed $85 \%$ for the case of potassium hydroxide. The third order of reaction was determined. The reaction rate constants and apparent activation energies were calculated. The activation energies were found to be almost equal for both used alkoxides $\left(30.5 \mathrm{~kJ} \mathrm{~mol}^{-1}\right)$. The features of the formation of glycerol layer were studied; this layer appeared during transesterification using potassium butoxide. Alkaline solutions of catalysts in butanol were studied by IRspectroscopy. The degeneracy of valence vibrations of $\mathrm{OH}$-groups in the region of about $3300 \mathrm{~cm}^{-1}$ was observed with as an increase in the potassium butoxide concentration. This may be due to the formation of associates of butanol and butoxide. The fundamental differences between reaction stages of methanolysis and butanolysis, caused by low dissociation degree of potassium butoxide in low polar butanol, were discussed. The ways of the formation of potassium glyceroxide and its role in the further course of the process were considered.
\end{abstract}

Keywords: butyl esters of fatty acids, potassium butoxide, potassium hydroxide, potassium glyceroxide, glycerol layer, alkoxide-anion formation.

DOI: $10.32434 / 0321-4095-2019-126-5-93-103$

\section{Introduction}

As opposed to widespread methyl esters of fatty acids (FAME), butyl esters of fatty acids (FABE) are not a large-tonnage chemical product. A growing interest in FABE production is directly connected with the spreading of biotechnological synthesis of butanol-1. First of all, butyl esters are regarded as an alternative to FAME as biodiesel fuel. Generally, they also may be useful in any other technical area where methyl esters are utilized. One can find information about the usage of FABE as technical fluids [1,2]. They can serve as raw materials for production of valuable chemical products, for example, multifunctional additives to lubricants [3]. Nowadays, butyl esters are produced by two-step synthesis from fatty acids. One-step production by homogeneous alkaline transesterification (TE) of oils, that is typical of methyl esters, creates difficulties related with high stability of the formed emulsions and separation of butyl esters and glycerol phase. However, it has been shown recently that spontaneous dividing of products is possible when the process is carried out using water-free potassium butoxide [4].

The aim of this work was to compare the characteristics of alkaline transesterification of 
sunflower oil over hydroxide and water-free alkoxide catalysts and to treat the observed features from the point of view of the mechanism of the transesterification reaction.

\section{Experimental}

Refined sunflower oil (triglycerides content of $99.9 \%$, density of $0.920 \mathrm{~g} / \mathrm{cm}^{3}$, acid value of 0.08 $\mathrm{mg} \mathrm{KOH} / \mathrm{g}$ ) was produced by JSC "Nizhynsky zhyrcombinat" (Nizhyn, Ukraine) according to Ukrainian state standard DSTU 4492:2005; it was used as raw-stuff for transesterification. The oil had the following fatty acid composition: palmitic $6.6 \%$, stearic $2.9 \%$, oleic $34.8 \%$, linoleic $54.3 \%$, linolenic $0.2 \%$ and other fatty acids $1.2 \%$. Reagent grade nbutyl alcohol (99.8\%) was used as a transesterification agent.

Alkaline catalysts were used in the form of their solutions in butanol. Potassium hydroxide (analytical grade, Czech Republic) was dissolved immediately before synthesis. Potassium butoxide solution was obtained by means of water removing together with water-butanol heterogenic azeotrope during azeotropic drying of $\mathrm{KOH}$ in n-butyl alcohol solution according to technique described elsewhere [5]. Both water contained in the initial alkaline reagent and water aroused by the following reaction (1) of butoxide formation were removed by azeotropic distillation.

$$
\mathrm{C}_{4} \mathrm{H}_{9} \mathrm{OH}+\mathrm{KOH} \leftrightarrow \mathrm{C}_{4} \mathrm{H}_{9} \mathrm{OK}+\mathrm{H}_{2} \mathrm{O} .
$$

Anhydrous potassium methylate for comparative syntheses was prepared by the reaction of $\mathrm{KOH}$ with methyl alcohol followed by numerous repeating cycles of alcohol-water mixture sequential distillation, its condensation and dehydration over zeolite KA and returning of methanol to reaction media.

The FTIR-spectra of alkali catalysts and potassium glyceroxide solutions were recorded by Shimadzu IRAffinity-1S infrared spectrometer equipped with ATR accessory Speacac GS 10801-B.

Transesterification reaction was carried out in a flat-bottom conical flask at the temperature of 20 and $40^{\circ} \mathrm{C}$ and at a molar ratio of alcohol to oil $\left(\mathrm{R}_{\mathrm{AO}}\right)$ equal to 6 . The amount of alkali catalyst (hydroxide $\mathrm{KOH}$, butoxide $\mathrm{KOBu}$ or methoxide $\mathrm{KOMe}$ ) in all syntheses was $0.95 \%$ relative to oil in terms of $\mathrm{K}$. Stirring $(500 \mathrm{rpm})$ and maintenance of a desired temperature of reaction mixture was performed by magnetic stirrer with heating and water bath.

Residual potassium content in fabricated butyl esters was determined by acid-base titration of the sample probe dissolved in dimethylformamide by picric acid with bromothymol blue.
TE reaction progress was controlled by gaschromatographic analysis of samples of the reaction mixture $(\approx 0.1-0.2 \mathrm{~g})$ using Agilent $7890 \mathrm{~A}$ gas chromatograph. Methylheptadecanoat (SigmaAldrich, for GC) was used as an internal standard for quantitation of the content of fatty acid esters. The method of analysis is described in more detail elsewhere $[4,6]$. The probes taken in given moments of time were immediately transferred into preprepared solutions of standard in n-hexane. The probes were diluted 20 times or higher, thus the reaction stopped. The yield of esters was calculated in $\%$ in terms of a maximal theoretically possible value.

In case of butanolysis, oil is well soluble in butanol, whereas the methanol-based TE implies that the reaction is performed during mixing of mutually insoluble liquids. The formation of a homogeneous mixture of oil and butyl alcohol occurs after a couple of seconds of intense mixing. Therefore, butanolysis of oils is a «true» homogeneous reaction and its rate is a function of reagents concentrations and does not require the accounting of mass transfer across phases interface. However, the study of «real» TE kinetics of triglycerides of oils is not possible based on only kinetic curves of the yield of esters. The reaction pathways of butanol-based TE include three chemically equal sequential-parallel equilibrium catalytic reactions:

$$
\begin{aligned}
& \mathrm{TG} \stackrel{+ \text { +Вион/кат. }}{\longrightarrow} \mathrm{DG}+ \\
& +\mathrm{FABE} \stackrel{+ \text { Вион/кат. }}{\longrightarrow} \mathrm{MG}+ \\
& +\mathrm{FABE} \stackrel{+ \text { Вион/кат. }}{\longleftrightarrow} \mathrm{Glyc}+\mathrm{FABE},
\end{aligned}
$$

where TG, DG and MG are tri-, di- or monoglyceride, respectively; FABE is butyl ester of fatty acid; and Glyc is glycerol.

Real kinetic parameters of each stage should be calculated based on time concentration changes of TG, DG and MG [7]. This requires using sophisticated and expensive chromatographic techniques. Therefore, we used simplified formal kinetic models, dealing with the concentration of nominal fragments $G$ of molecules of glycerides, which contain one ester bond:

$\mathrm{G}=\frac{1}{3} \mathrm{TG} \approx \frac{1}{2} \mathrm{DG} \approx \mathrm{MG}$.

Using this simplistic approach implies that TE of each ester bond in molecules of glycerides occurs independently and the reaction scheme (2) takes 
the following form:

$3 \mathrm{G}+3 \mathrm{BuOH} \leftrightarrow 3 \mathrm{FABE}+\mathrm{Glyc}$.

This allows expressing the change of $G$ concentration using known FABE concentrations and fitting the formal kinetic equations in the following form:

$$
-\frac{\mathrm{dC}_{\mathrm{G}}}{\mathrm{d} \tau}=\mathrm{k} \cdot \mathrm{C}_{\mathrm{G}}^{\mathrm{n}}
$$

where $\mathrm{n}$ is the apparent reaction order of TE reaction with respect to glycerides fragments $G, k$ is the reaction rate constant.

The concentration of $\mathrm{BuOH}$ taken in essential excess was not included in the reaction rate equation.

The graphic method was used to determine the values of $\mathrm{n}$ and $\mathrm{k}$. It implies plotting the dependences $\ln \mathrm{C}_{\mathrm{g}}=\mathrm{f}(\tau), 1 / \mathrm{C}_{\mathrm{G}}=\mathrm{f}(\tau), 1 / \mathrm{C}_{\mathrm{G}}^{2}=\mathrm{f}(\tau)$, corresponding to linearized form of kinetic equation (5) of the first, second and third order with respect to $\mathrm{G}$, respectively. The rate constant, $\mathrm{k}$, was determined from the slope of the straight line, which approximates the corresponding dependence.

The apparent activation energy of butanolysis reaction over each catalyst was calculated according to the following formula

$$
\mathrm{E}_{\mathrm{a}}=\frac{\mathrm{R} \cdot \mathrm{T}_{1} \cdot \mathrm{T}_{2} \cdot \ln \left(\frac{\mathrm{k}_{2}}{\mathrm{k}_{1}}\right)}{\mathrm{T}_{2}-\mathrm{T}_{1}} .
$$

\section{Results and discussions}

Figure 1 shows kinetic curves of the decrease in the concentration of glyceride fragments $G$ (a) and FABE yield (b) with the reaction time at 20 and $40^{\circ} \mathrm{C}$. The time required to equilibrium establishment did not exceed 30-60 min, and no sufficient change in reaction equilibrium state was observed after $60 \mathrm{~min}$ of synthesis. The highest equilibrium yield of esters was obtained over KOBu catalyst (95-96\%), whereas the lowest equilibrium yield was achieved over $\mathrm{KOH}$ catalyst (79-85\%). The equilibrium yield of esters in the synthesis over methoxide catalyst was very close to that of over butoxide over (only lower by $3-4 \%$ ). However, in this case, FAME is formed together with FABE. The highest concentration of the FAME in the reaction mixture $(6-7 \%)$ was observed in the very beginning of the synthesis. After this, it gradually decreased to $4-5 \%$ with reaction time. This, obviously, is due to the transesterification of FAME by butyl alcohol.
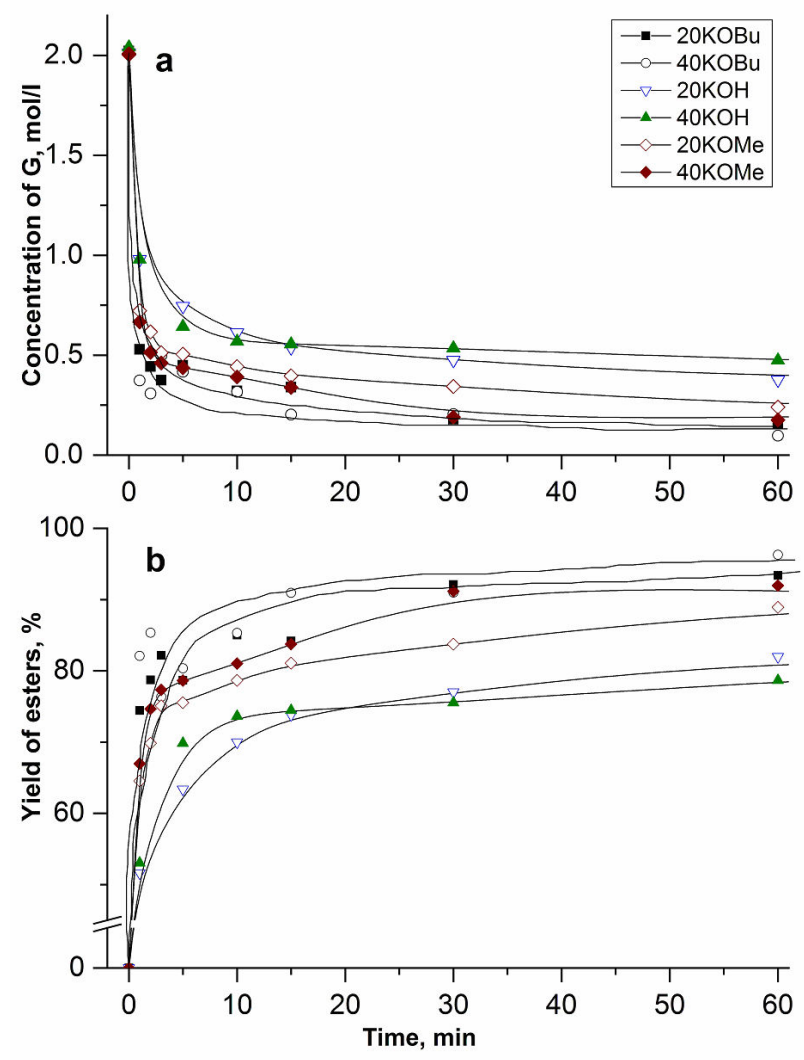

Fig. 1. Concentration of glycerides fragments $G$ (a) and esters yield (b) as a function of reaction time

Specified quantities of formed methyl esters do not exceed $50-60 \%$ with respect to the theoretically possible amount, which means that no methoxide and methanol in it were spent in the reaction.

For all experiments, the dependences $1 / \mathrm{C}_{\mathrm{G}}^{2}$ vs. $\tau$ appeared to be linear. This indicates the third order of kinetic equation (5) with respect to G. The kinetic parameters of the reaction occurring over each catalyst were calculated (Table 1). The values of the TE reaction rates over different catalyst, calculated from the obtained equation, are given in Table 2.

The reaction rate constants and initial reaction rates with respect to glycerides fragments are notably higher for $\mathrm{KOBu}$ catalyst than those for methoxide catalyst. Being very high from the very beginning of the synthesis, the rate of butanolysis drastically decreases after second minute. The drop of reaction rate reaches two orders of magnitude. The activation energies appeared to be very close for both alkoxides. It should be taken into account that $E_{a}$ values calculated in such a way are somewhat formal, averaged over three stages of the reaction scheme (2).

Essentially different character of the reaction 
Kinetic parameters of transesterification of sunflower oil by butanol over different catalysts

\begin{tabular}{c|c|c|c|c|c}
\hline \multirow{2}{*}{ Catalyst } & $\mathrm{k}_{1} \cdot 10^{3}, \mathrm{~L}^{2} /\left(\mathrm{mol}^{2} \cdot \mathrm{s}\right)$ & $\mathrm{R}^{2}$ & $\mathrm{k}_{1} \cdot 10^{3}, \mathrm{~L}^{2} /\left(\mathrm{mol}^{2} \cdot \mathrm{s}\right)$ & $\mathrm{R}^{2}$ & \multirow{2}{*}{$\mathrm{E}_{\mathrm{a}}, \mathrm{kJ} / \mathrm{mol}$} \\
\cline { 2 - 5 } & \multicolumn{2}{|c|}{$20^{\circ} \mathrm{C}$} & \multicolumn{2}{|c|}{$40^{0} \mathrm{C}$} & \\
\hline $\mathrm{KOBu}$ & 5.91 & 0.94 & 13.25 & 0.91 & 30.8 \\
\hline $\mathrm{KOMe}$ & 2.10 & 0.97 & 4.67 & 0.91 & 30.5 \\
\hline $\mathrm{KOH}$ & 1.83 & 0.94 & 2.27 & 0.92 & 8.2 \\
\hline
\end{tabular}

Note: $*$ the values were calculated for the reaction time interval of $1-10 \mathrm{~min}$.

Table 2

Calculated values of the reaction rate of sunflower oil transesterification

\begin{tabular}{|c|c|c|c|c|}
\hline \multirow[t]{2}{*}{ Catalyst } & $\begin{array}{c}\text { Initial rate, } \\
\mathrm{mol} /(\mathrm{L} \cdot \mathrm{s})\end{array}$ & $\begin{array}{c}\text { Average rate }(1-10 \mathrm{~min}), \\
\mathrm{mol} /(\mathrm{L} \cdot \mathrm{s})\end{array}$ & $\begin{array}{c}\text { Initial rate, } \\
\mathrm{mol} /(\mathrm{L} \cdot \mathrm{s})\end{array}$ & $\begin{array}{c}\text { Average rate }(1-10 \mathrm{~min}), \\
\mathrm{mol} /(\mathrm{L} \cdot \mathrm{s})\end{array}$ \\
\hline & \multicolumn{2}{|r|}{$20^{\circ} \mathrm{C}$} & \multicolumn{2}{|r|}{$40^{\circ} \mathrm{C}$} \\
\hline $\mathrm{KOBu}$ & $2.48 \cdot 10^{-2}$ & $5.33 \cdot 10^{-4}$ & $5.51 \cdot 10^{-2}$ & $5.55 \cdot 10^{-4}$ \\
\hline$\overline{\mathrm{KOMe}}$ & $8.91 \cdot 10^{-3}$ & $4.87 \cdot 10^{-4}$ & $1.95 \cdot 10^{-2}$ & $8.30 \cdot 10^{-4}$ \\
\hline $\mathrm{KOH}$ & $8.33 \cdot 10^{-3}$ & $1.07 \cdot 10^{-3}$ & $1.07 \cdot 10^{-2}$ & $1.27 \cdot 10^{-3}$ \\
\hline
\end{tabular}

progress was observed when $\mathrm{KOH}$ was used as a catalyst. In this case, satisfactory reliability of approximation was achieved for only initial interval $(0-10 \mathrm{~min})$ of kinetic curves. The rate constant of butanolysis over $\mathrm{KOH}$ at $20^{\circ} \mathrm{C}$ was almost the same as that over methoxide (Table 1). At the same time, the value of $\mathrm{k}$ increases very insignificantly when increasing temperature, which results in a low activation energy. This may be due to an increase in the rate of a competitive reaction of saponification of both glycerides and butyl esters, which is impossible in the case of water-free synthesis over alkoxides. A lower equilibrium yield of esters at a higher temperature after $6 \mathrm{~h}$ of synthesis $(79 \%$ and $85 \%$ at $40^{\circ} \mathrm{C}$ and $20^{\circ} \mathrm{C}$, respectively) may be also caused by the reactions of soap formation. Generally, butanolysis reaction, catalyzed by potassium hydroxide, is characterized by smoother kinetic curves (Fig. 1) and far less pronounced drop of the reaction rate after first minute of the synthesis (Table 2).

Transesterification of sunflower oil by butanol over KOBu catalyst, likewise TE of rapeseed oil [4], was accompanied by the cloudiness of the reaction mixture after first two minutes of stirring. This indicates the beginning of the separation of the formed free glycerol product into an individual phase. It was precipitated in the course of the synthesis, forming highly basic dense and viscous residue, primary glycerol layer (GL), on the bottom of the reaction flask. After $6 \mathrm{~h}$ of the synthesis, its amount was $3.7 \%$ and $4.1 \%$ relative to oil at the temperatures of $20^{\circ} \mathrm{C}$ and $40^{\circ} \mathrm{C}$, respectively.

It should be mentioned that the maximal theoretical amount of glycerol, able to form from TG of vegetable oils, is near $10-11 \%$ of its weight.
When using methoxide, the cloudiness of reaction mixture also occurred at both temperatures, but the formation of primary GL (2.2\% relative to oil) was observed only at $20^{\circ} \mathrm{C}$. It was somewhat more fluid that in the case of using KOBu. Neither the cloudiness of reaction media nor spontaneous separation of TE products was detected during the synthesis over hydroxide. After sedimentation over $24 \mathrm{~h}$ at an ambient temperature, some small amounts of secondary GL additionally was separated from the reaction products over $\mathrm{KOBu}$ (both at $20^{\circ} \mathrm{C}$ and $40^{\circ} \mathrm{C}$ ) and over $\mathrm{KOMe}$ (only at $20^{\circ} \mathrm{C}$ ). The results of analysis of potassium content in ester layers after TE are shown in Table 3 . In the case of syntheses accompanied by separation of GL, quite low concentrations of residual potassium were fixed, which indicates the transfer of the bulk of alkali catalyst to GL.

Table 3

\section{Residual potassium content in ester layers after} transesterification of sunflower oil by butanol

\begin{tabular}{l|c|c}
\hline Coditions of synthesis & $\mathrm{K}, \%$ & $\mathrm{~K}, \%$ of loaded \\
\hline $\mathrm{KOBu}\left(20^{\circ} \mathrm{C}\right)$ & 0.028 & 2.8 \\
\hline $\mathrm{KOBu}\left(40^{\circ} \mathrm{C}\right)$ & 0.038 & 3.9 \\
\hline $\mathrm{KOMe}\left(20^{\circ} \mathrm{C}\right)$ & 0.065 & 7.9 \\
\hline $\mathrm{KOMe}\left(40^{\circ} \mathrm{C}\right)$ & 0.812 & 88.9 \\
\hline $\mathrm{KOH}\left(20^{\circ} \mathrm{C}\right)$ & 0.851 & 92.7 \\
\hline $\mathrm{KOH}\left(40^{\circ} \mathrm{C}\right)$ & 0.860 & 93.8 \\
\hline
\end{tabular}

The features of GL formation during butanolysis can be more precisely examined at lower reaction temperature and alcohol excess than those that were used in previous kinetic experiments. Figure 2 shows the yields of FABE (a) and GL amounts (b) obtained 
in the synthesis at $15^{\circ} \mathrm{C}$ and $\mathrm{R}_{\mathrm{AO}}=4.5$. The amount of the KOBu was the same (0.95\%). Each point in this experiment corresponds to separate synthesis. The yields of FABE were determined both immediately after stirring and after settling of products over $24 \mathrm{~h}$. The amounts of primary GL and secondary GL formed after settling are given in \% relative to the mass of oil. The FABE yield achieved after 60 min of stirring was sufficiently lower than that obtained in previous syntheses using butoxide (Fig. $1, b)$. At the same time, the yield of esters after full separation of secondary GL appeared to be almost invariably high $(\geq 90 \%) 6$ independently of the synthesis duration. Moreover, at nominal zero time (only intensive mixing during 2-3 s was performed), the yield of ester was as high as $89 \%$. The mass of primary GL gradually increases with time, its formation starts after 2 min of synthesis. The change in the secondary GL mass was opposed directed to the change in the mass of primary GL. The total amount of GL was slightly lower than the theoretically possible mass of reaction glycerol containing all potassium loaded.

Chromatographic analysis of secondary GL shows only minor impurities of FABE and butyl alcohol $(<1 \%)$ in its composition. Likewise primary $\mathrm{GL}$, it also was high-dense $\left(1.40 \mathrm{~g} / \mathrm{cm}^{3}\right)$, viscous and strongly basic. The approximate molar ratio of potassium to glycerol was 1:6.

An unusual character of alkaline butanolysis reflects the features of the mechanism of the TE reaction in «dry» conditions when using butoxide catalyst. Figure 3 shows IR-spectra of butanol solutions of potassium butoxide and hydroxide together with the spectrum of pure n-butyl alcohol. The concentrations of corresponding solutions are given in Table 4.

The intensity of the absorption bands at 2840$3000 \mathrm{~cm}^{-1}$, corresponding to stretching vibrations of $\mathrm{C}-\mathrm{H}$ bonds of $\mathrm{sp}^{3}$-hybridized carbon atoms, are equal for all samples. No frequency shifts are observed. Stretching vibrations of $\mathrm{C}-\mathrm{O}$ groups in IR-spectrum of alcohol are presented by a doublet of absorption bands at 1040 and $1070 \mathrm{~cm}^{-1}$. With increasing concentration of butoxide solution, the mentioned bands are merged. This may be caused by the influence of potassium atoms of $\mathrm{KOBu}$ on this $\mathrm{C}-$ $\mathrm{O}$ bond and, probably, by the formation of stable structures of butoxide and molecules of alcohols.

The absorption intensity of valence vibrations of $\mathrm{O}-\mathrm{H}$ bonds around $3300 \mathrm{~cm}^{-1}$ changes most significantly from spectrum to spectrum. It is generally known that the vibrations of free separate $\mathrm{OH}-$ bonds produce a narrow band in the region of $3670-3850 \mathrm{~cm}^{-1}$. A wide absorption band is specific for water solutions and alcohols when hydrogen bonds
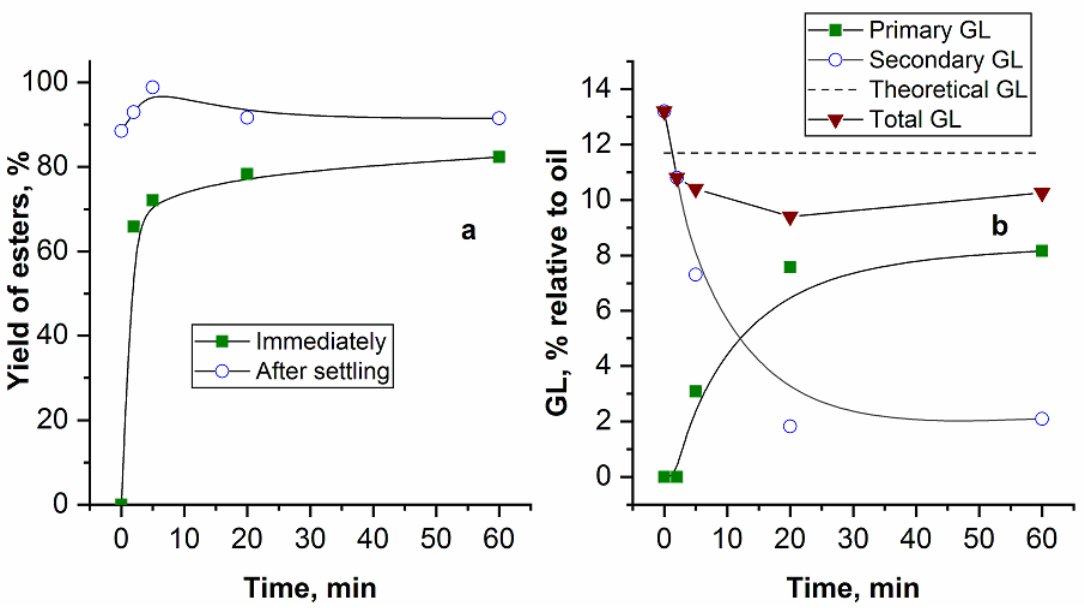

Fig. 2. Yield of butyl esters (a) and GL amounts (b) formed during transesterification of sunflower oil by butanol over potassium butoxide $\left(\mathrm{R}_{\mathrm{AO}}=4.5\right)$

Table 4

Solutions of alkali catalysts used for IR-spectroscopy

\begin{tabular}{l|c|l}
\hline \multicolumn{1}{c|}{ Sample } & Concentration, \% of K & \multicolumn{1}{c}{ Praparation procedure } \\
\hline IR-KOH & 2.2 & Dissolving of hydroxide without drying \\
\hline IR-KOBu-1 & 4.0 & Direct synthesis from KOH and butanol with drying \\
\hline IR-KOBu-2 & 8.9 & Direct synthesis from KOH and butanol with drying \\
\hline IR-KOBu-3 & 24.4 & Concentration of IR-KOBu-1 \\
\hline
\end{tabular}

Alkaline transesterification of sunflower oil triglycerides by butanol-1 over potassium hydroxide and alkoxides catalysts 


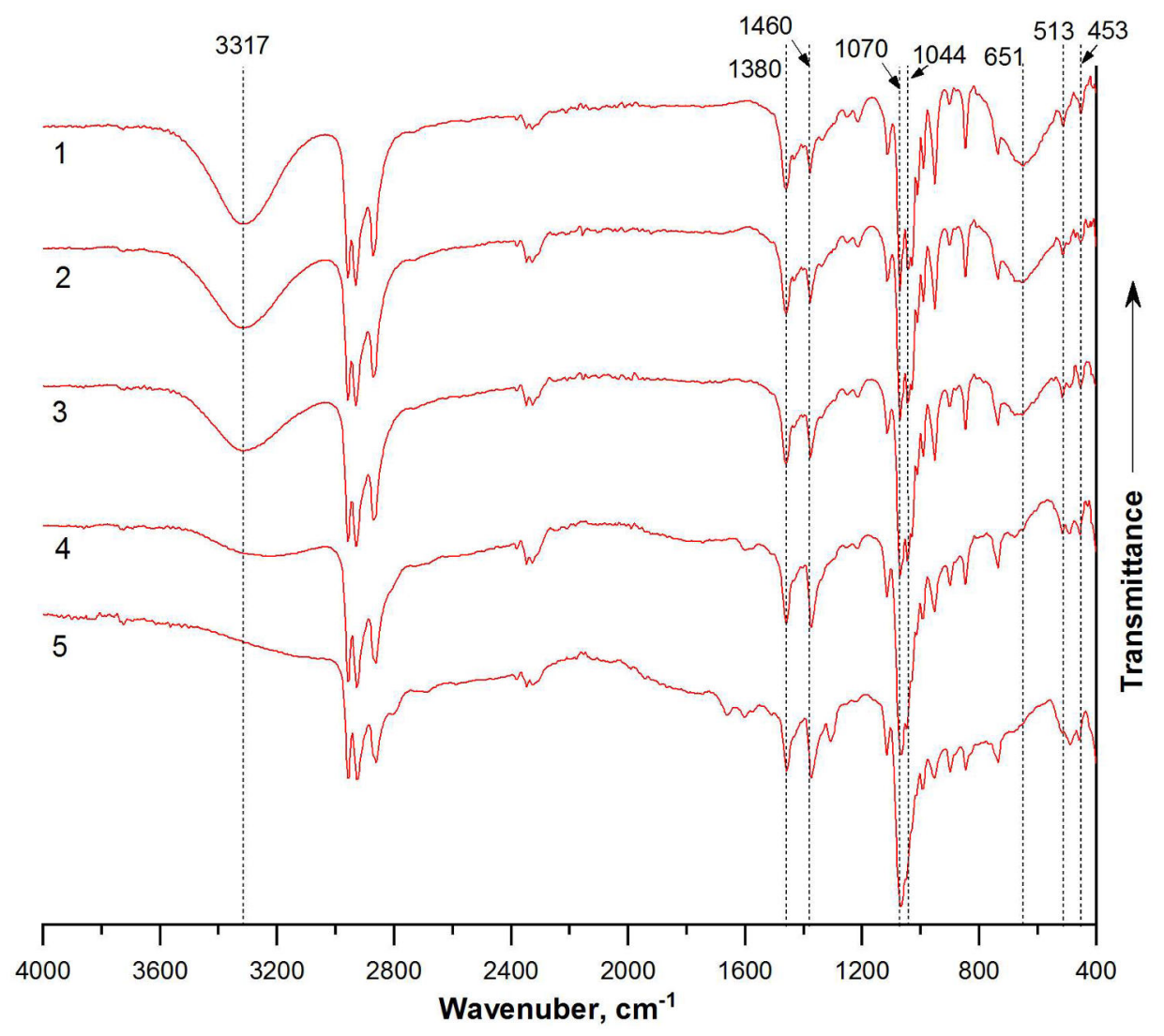

Fig. 3. IR-spectra of butanol solutions of alkaline catalysts and n-butanol: (1) - n-butanol; (2) - IR-KOH; (3) - IR-KOBu-1; (4) - IR-KOBu-2; (5) - IR-KOBu-3

are formed. In the case of butanol and hydroxide solution (Fig. 3, spectra 1 and 2), stretching vibrations of $\mathrm{O}-\mathrm{H}$ bonds are presented by a wide and intensive band. In the case of butoxide samples, the intensity of this band decreases with an increase in the concentration. In addition, the shift of absorption maximum occurs towards lower frequencies. In the spectrum of the most concentrated solution, this band almost disappears. This cannot be due to the absence of $\mathrm{OH}$-groups or hydrogen bonds, because even the sample IR-KOBu- 3 contains approximately $30 \%$ of butanol. It is known that the so-called chelate or intramolecular hydrogen bonds are hard to determine by IR-spectroscopy without deuteron exchange [8]. In addition, it was earlier shown that lithium tertbutoxide exists in the form of the cyclic trimer, formed by $\mathrm{Li}-\mathrm{O}$ bonds, both in crystal state and in solutions [9]. More likely, that this pronounced decrease of absorption intensity at $3300 \mathrm{~cm}^{-1}$ is caused by existing stable intermolecular formation of butanol and potassium butoxide. The molar ratio between these components allows us to suggest that such structures may be presented by hexamer consisted of two molecules of butoxide and four molecules of butanol. The formation of these structures should hinder free oscillations along $\mathrm{O}-\mathrm{H}$ bond line. Similar to the latter, the intensity of the band at $651 \mathrm{~cm}^{-1}$, produced from out-of-plane vibration of $\mathrm{OH}$-groups [10], also decreases (up to vanishing).

It was also found that additional absorption band between week bands at 453 and $513 \mathrm{~cm}^{-1}$ arouses in spectra of butoxide solutions. Its intensity increases while increasing the concentration of the solutions. The frequency, corresponding to these vibrations, is close to that ascribed to vibrations of $\mathrm{O}-\mathrm{K}$ bond in potassium tert-butoxide molecule [9].

Thus, the results of IR-spectroscopy of alkaline catalyst solutions argue in favor of the formation of associates between molecules of butyl alcohol and potassium butoxide. As degeneracy of oscillations $\mathrm{O}-\mathrm{H}$ bonds actually occurs, the strength of this association may be significantly high.

The following question arises: in what way do the observed features affect the mechanism of alkaline butanolysis of vegetable oil? Commonly, the mechanism of TE over alkaline catalysts is discussed using the example of the well-studied and widespread process of methanolysis. In the case of alkali metal 
hydroxide catalyst, the mechanism is usually presented in such a manner that the catalyst is restored in the last stage directly with the formation of hydroxide. Then, the latter reacts again with methanol forming methoxide anion, and a new cycle of TE begins [11]. Another way of catalyst restoration during alkali TE, which is more correct from our point of view, have been proposed by Guo and Fang [12]. This way consists in proton elimination from the next molecule of methanol by tetrahedral intermediate, which is formed after the nucleophilic attack of carbonyl group of glycerides by alkoxideanion. Proton is consumed for restoring $\mathrm{OH}$-group of glyceride, and alkali catalyst is restored in its real active form, namely in the form of alkoxide-anion. In this case, the cycle of transformation is closed up without returning to initial hydroxide. In the same way, methanolysis or ethanolysis reactions may occur when using commercially available alkali metal alkoxides, which are dissociated into a metal cation and corresponding alkoxide anion in strongly polar solvents.

Another situation occurs during TE by butyl alcohol. Electron density on the oxygen atom of butyl alcohol is higher than in the case of methyl alcohol. This is due to increasing the positive inductive effect of hydrocarbon radicals when lengthening their carbon chain, which results in lower polarity of $\mathrm{OH}$-bond of butanol. So, one can expect sufficiently low degree of dissociation of butoxide, dissolved in butanol as compared with that of methoxide in methanol media. Therefore, the possibility of existing free anions $\mathrm{BuO}^{-}$in the reaction mixture and their action as a catalyst of TE process seems to be doubtful. However, butanolysis over KOBu catalyst has a very high reaction rate, especially in the very beginning of the synthesis (see Fig. 1 and Table 2).
From our point of view, butoxide-anion during alkaline butanolysis of glycerides may form in a way, as it is formed over solid catalysts. Boey et al. [13], when treating the methanolysis over solid catalyst $\mathrm{CaO}$, postulated the formation of anion $\mathrm{MeO}^{-}$by means of alcohol molecule polarization over calcium oxide. In our case, this may occur as follows. Atoms of oxygen and potassium in butoxide molecule are characterized by week nucleophilic and electrophilic properties, respectively. Thus, when butanol (I) molecule interacts with $\mathrm{KOBu}$ (II) the polarization of bonds occurs (Scheme 1). The partially negative charge on the oxygen atom of butoxide (II) pulls proton of butanol (I) on itself, while the partially positive charge on potassium appropriately orients butoxide-anion (Scheme 1). This promotes further heterolytic cracking of alcohol OH-bond.
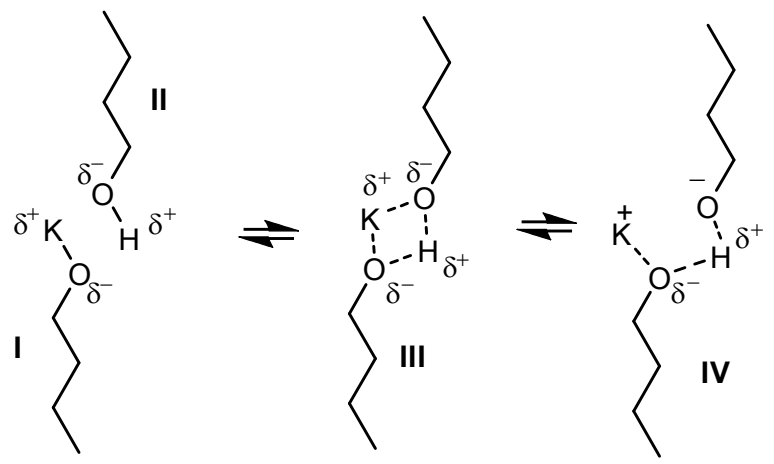

Scheme 1

Butoxide-anion (IV), activated in such a way, attacks carbon atom of the carbonyl group of triglyceride $(\mathrm{V})$, forming transition structure, tetrahedral intermediate VI (Scheme 2).

Intermediate VI is decomposed with the formation of butyl ester (VII) and corresponding
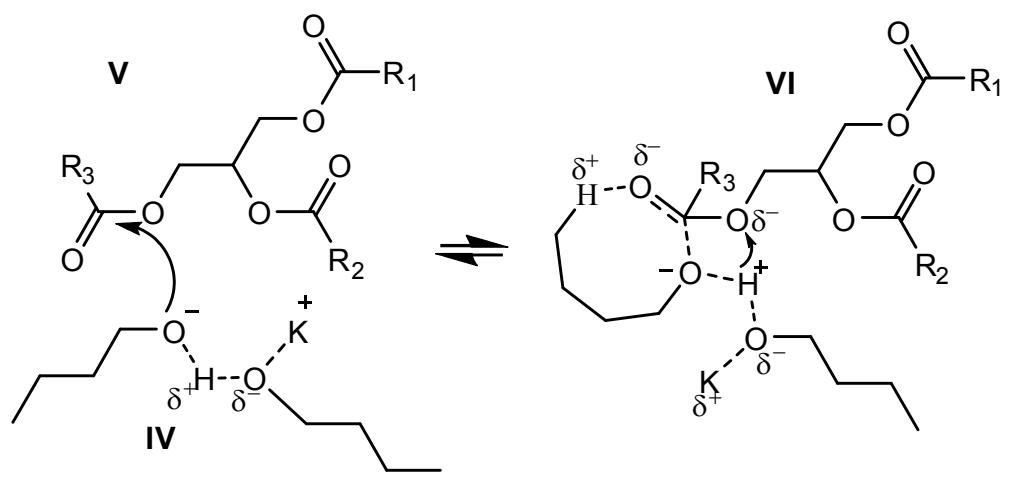

$\mathrm{R}_{1}, \mathrm{R}_{2}, \mathrm{R}_{3}$ - fatty acid radicals

Scheme 2

Alkaline transesterification of sunflower oil triglycerides by butanol-1 over potassium hydroxide and alkoxides catalysts 

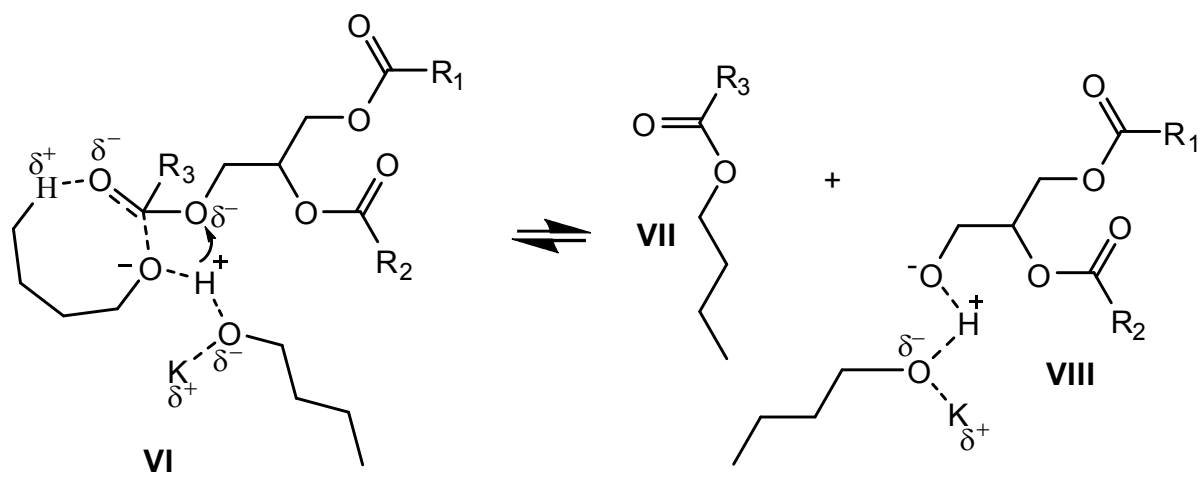

Scheme 3
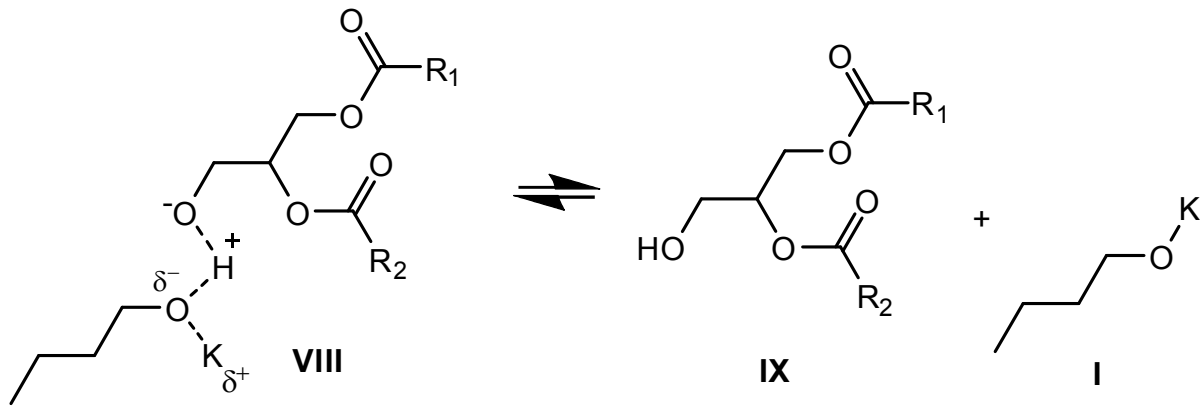

Scheme 4

anion of digliceride (VIII), which is associated with butoxide (Scheme 3).

Next stage (Scheme 4) stipulates restoring $\mathrm{OH}-$ group of DG and catalyst in the form of butoxide (I). The further successive substitution of radicals $R_{1}$ and $R_{2}$ in molecules of $D G$ and $M G$ occurs in the same manner.

According to presented reaction sequence after last stage (TE of MG molecule), free glycerol should be formed and alkali catalyst should be recovered in an unchanged state (i.e. in the form of butoxide I). However, it is generally known that di- and triatomic alcohols are characterized by stronger acidity than those of monoatomic alcohols. This is due to the counteraction of negative inductive effects $\left(-\mathrm{I}_{\mathrm{ef}}\right)$ of oxygen atoms of hydroxyl groups attached to the adjacent carbon atoms. In addition, the known numerical values of alcohols dissociation constants are applicable only to diluted water solutions; it is able to be useful for some estimation comparison of relative acidity of alcohols under the conditions of alkaline TE of oils. It is known that $\mathrm{pK}_{\mathrm{a}}\left(25^{\circ} \mathrm{C}\right)$ of methanol and glycerol is equal to 15.5 and 14.4, respectively [14]. n-Butyl alcohol, having three atoms on a longer carbon chain, reveals weaker acid properties as compared with methanol $\left(\mathrm{pK}_{\mathrm{a}}=16.1\right.$ [15]). Thus, the relative difference of acidity between glycerol and n-butanol is almost two orders of magnitude. Hence, the transition of potassium to glyceroxide-anion during the last stage of TE is highly probable (Scheme 5). As a result, potassium glyceroxide is formed. It can also activate butoxide anion XII as this takes place during the stage showed in Scheme 1. The latter, involving into catalysis of butanolysis reaction, finally leads to the formation of free glycerol associated with glyceroxide (XIII).

According to the developed reaction pathways, alkaline catalyst is not fully restored in its initial form, but mainly is transferred into another active form of potassium glyceroxide. In our opinion, the formation of glycerol-glyceroxide associates XIII, which are inclined to further aggregation, gives rise to spontaneous separation of GL during alkaline butanolysis. Because of the aggregation of associates XIII, the catalyst begins to come out from the contact with reagents molecules, and TE reaction continues mainly on the surface of micellar structures, solubilizing glycerol and glyceroxide in itself. Probably, the transition from homogeneous catalysis involving potassium butoxide to virtually heterogeneous one over potassium glyceroxide causes a sharp decrease in the reaction rate of butanolysis already after the first minute of the process (Fig. 1). On the other hand, a slow increase in the FABE yield after a very high initial reaction rate may be due to the slow shift of reaction equilibrium towards 
<smiles>[Y]O[CH+][CH]OCC(O)CO</smiles>

$\mathbf{X}$

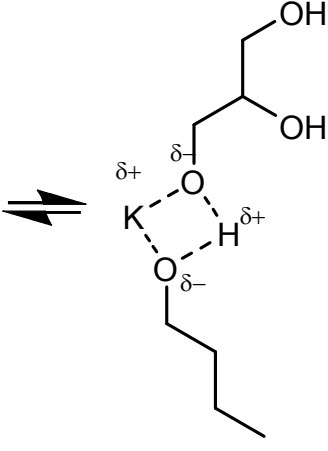

$\mathbf{X} \mathbf{I}$<smiles>C=C[Te]O[C]([18OH])OCC(O)CO</smiles><smiles></smiles>

XIII

Scheme 5

forming of TE products as glycerol gradually removes from reaction media. Most likely, potassium glyceroxide also contributes to TE catalysis during the separation sedimentation of products of the FABE alkali synthesis (Fig. 2) and reaction mainly occurs on the surface of slowly settling micellar structures.

It should be emphasized that epy disclosed reaction sequence of alkali butanolysis may be strongly complicated by the participation of potassium salts of MG and DG in the catalysis process. These salts, likewise glycerol, should be stronger acids as compared with butanol because of the counteraction of $-\mathrm{I}_{\mathrm{ef}}$ of hydroxyl and ester groups. Consequently, the formation of potassium salts of glycerides, that are also able to activate alkoxideanion, is more likely than restoring of $\mathrm{KOBu}$. However, their participation in catalysis of transesterification may be strongly restricted by steric hindrances.

IR-spectrum of secondary GL prepared by the synthesis at $\mathrm{R}_{\mathrm{AO}}=4.5$ (Fig. 4) argues in favor of the validity of the proposed mechanism. The spectrum does not contain absorption band of carbonyl group (near $1700 \mathrm{~cm}^{-1}$ ) and fully repeats the spectrum of the potassium glyceroxide solution in pure glycerol. Abovementioned value of the molar ratio of $\mathrm{K}$ to glycerol in studied secondary GL indicates that approximately 5 molecules of free glycerol accounts for one molecule of glyceroxide.

It should be also emphasized that spontaneous removal of glycerol together with potassium glyceroxide during the synthesis is a determining factor that provides high equilibrium yield of esters when alkoxides are used. At the same time, the equilibrium yield is sufficiently low in a synthesis over KOH when no GL formation occurs (Fig. 1,b). In terms of the proposed mechanism, the absence of spontaneous separation of GL is caused by the difficulty of glyceroxide formation in the presence of water. $\mathrm{H}_{2} \mathrm{O}$ is characterized by higher acid strength comparing with both glycerol and butanol, which is indicated by the thermodynamically correct value of $\mathrm{pK}_{\mathrm{a}}$ that is equal to 14.0 [14].

In the case when KOMe is used as a catalyst, the existence of similar mechanism can be predicted. However, possible reaction pathways of TE are complicated by the simultaneous presence of both methoxide- and butoxide-anions in the reaction mixture, they are in the equilibrium. Methoxide, being weaker base, is able to recover more easily in the stage showed in Scheme 4, forming free glycerol or glyceride. This may cause a lower amount of

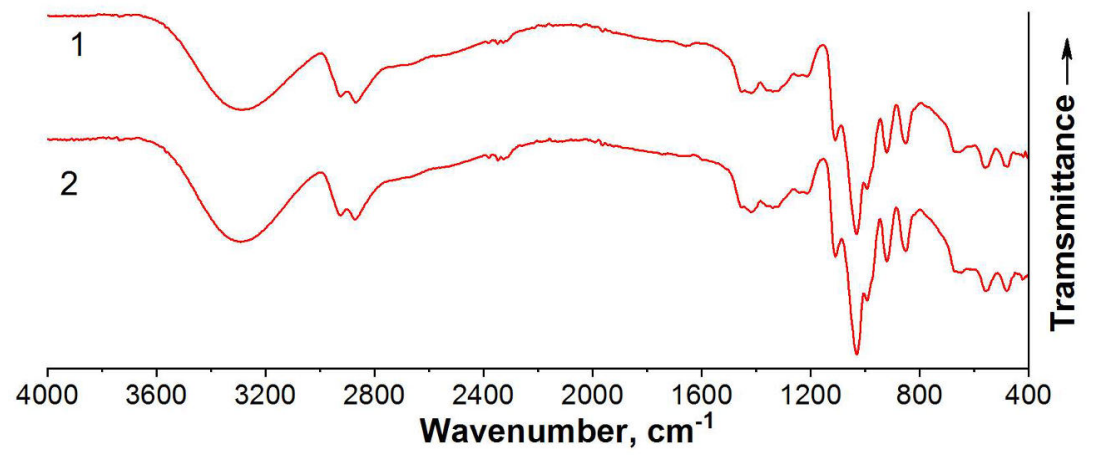

Fig. 4. IR-spectra of secondary GL (1) and potassium glyceroxide solution in glycerol (2) 
primary GL that is formed in the course of the synthesis over the KOMe catalyst.

\section{Conclusions}

It has been shown that alkaline transesterification of sunflower oil triglycerides by butyl alcohol shows the highest reaction rate over the potassium butoxide catalyst and the lowest one when using potassium hydroxide, while potassium methoxide provides a moderate reaction rate. In addition, the highest equilibrium yield of butyl esters (95-96\%) was observed over butoxide catalyst, which is contributed by the separation of glycerol layer directly during the synthesis, providing the shift of reaction equilibria towards the formation of products. It was found that the higher than $90 \%$ equilibrium yields of esters over butoxide is observed independently of the reaction time after the sedimentation of the products. A glycerol layer that is formed after the sedimentation consists of glycerol mixture with potassium glyceroxide and does not contain butyl esters, glycerides and butanol.

The observed decrease in the intensity of $\mathrm{OH}-$ groups band in IR-spectra of alkaline catalysts argued for the formation of significantly stable structures of butanol molecules and potassium butoxide. This allowed us to propose the scheme of reaction pathways, realizing during transesterification of vegetable oils by butanol, which differs from the metanolysis process in the way of alkoxide-anion formation in a less polar media of n-butyl alcohol.

The conception of preferential recovery of the alkaline catalyst during butanolysis in the form of glyceroxide and its role in the catalysis of transesterification reaction and separation of products were formulated. Suppression of glyceroxide formation by water in reaction media prevents spontaneous separation of the glycerol layer and leads to low equilibrium yield of butyl esters.

\section{REFERENCES}

1. Low-molecular-weight, fatty-acid esters as potential lowtemperature drilling fluids for ice coring/ Xu H., Han L., Cao P., Guo M., Han J., Yu D., Talalay P. // Ann. Glaciol. - 2014. Vol.55. - No. 68. - P.39-43.

2. Shereshevskiy A.I., Unanyants T.P., Bakharovskiy G.Ya. Khimicheskiye tovary: spravochnik, Chast' 1. - M.: Gosudarstvennoe nauchno-tekhnicheskoe izdatelstvo khimicheskoi literatury, 1961. $-1090 \mathrm{p}$.

3. Oleochemical synthesis of sulfanes, their structure and properties / Bodachivskyi I., Pop G., Zheleznyi L., et al. // Chem. Chem. Technol. - 2017. - Vol.11. - No. 3. - P.365371.
4. Patrylak L.K., Zubenko S.O., Konovalov S.V. Pereesteryfikatsiya ripakovoyi olii butanolom na luzhnykh katalizatorakh // Voprosy Khimii i Khimicheskoi Tekhnologii. 2018. - No. 5. - P.125-130.

5. Preparation of potassium butylate with potassium hydroxide and n-butyl alcohol for using in trigliceride transesterification process / S.O. Zubenko, S.V. Konovalov, L.K. Patrylak, M.V. Okhrimenko // Kataliz i neftekhimiya. - 2017. - No. 26. P.36-39.

6. Engine performance and emission of biodiesel fuel prepared from different Ukrainian natural oils / Patrylak L.K., Okhrimenko M.V., Levterov A.M., et al. // Chem. Pap. - 2019. - Vol.73. - No. 7. - P.1823-1832.

7. Likozar B., Levec J. Transesterification of canola, palm, peanut, soybean and sunflower oil with methanol, ethanol, isopropanol, butanol and tert-butanol to biodiesel: Modelling of chemical equilibrium, reaction kinetics and mass transfer based on fatty acid composition // Appl. Energy. - 2014. - Vol.123. P.108-120.

8. Kozitsyna L.A., Kupletskaya N.B. Primenenie UF-, IK-, YaMR- i mass-spektroskopii v organicheskoi khimii. - M.: Izdatel'stvo Moskovskogo universiteta, 1979. - 240 p.

9. Simonov A.P., Shigorin D.N. Infrakrasnyye spektry pogloshcheniya i stroenie tretichnogo butilata litiya. Optika i spectroskopiya. Sbornik statei 3. - M.: Nauka, 1957. - P. 244249.

10. Pretsch E., Buhlmann P., Affolter C. Structure determination of organic compounds. - New York: Springer, 2000. $-433 \mathrm{p}$.

11. Synthesis of biodiesel via acid catalysis / Lotero E., Liu Y., Lopez D.E., et al. // Ind. Eng. Chem. Res. - 2005. - Vol.44. No. 14. - P.5353-5363.

12. Guo F., Fang $Z$. Biodiesel production with solid catalysts / Biodiesel - feedstocks and processing technologies / Ed. M. Stoytcheva. - New York: InTechOpen, 2011. - P.339-358.

13. Boey P.-L., Maniam G.P., Hamid S.A. Performance of calcium oxide as a heterogeneous catalyst in biodiesel production: a review // Chem. Eng. J. - 2011. - Vol.168. - No. 1. - P.1522.

14. Silverstein T.P., Heller S.T. pKa values in the undergraduate curriculum: what is the real pKa of water? // J. Chem. Educ. - 2017. - Vol.94. - No. 6. - P.690-695.

15. Serjeant E.P., Dempsey B. Ionization constants of organic acids in aqueous solution (IUPAC chemical data series). - New York: Pergamon Press, 1979. - 998 p.

Received 22.04.2019

\section{ЛУЖНА ПЕРЕЕТЕРИФІКАЩЯ ТРИГЛІЩЕРИДІВ СОНЯШНИКОВОЇ ОЛІЇ БУТАНОЛОМ-1 НА ГЦДРОКСИДІ ТА АЛКОГОЛЯТАХ КАЛІЮ}

Л.К. Патриляк, С.О. Зубенко, С.В. Коновалов, В.А. Поважний 
Бутилові етери жирних кислот мають низку технічних застосувань та розглядаються як потенційне біодизельне паливо. Складність розділення продуктів, одержаних лужною переетерифікацією олій, є причиною обмеженої уваги дослідників до цього одностадійного шляху синтезу бутилових естерів. Метою иієї роботи було порівняти особливості лужної переетерифікаиії соняшникової олії на гідроксиді та безводних алкоголятах як каталізаторів і пояснити спостережені особливості з точки зору механізму реакції. Переетерифікацію виконували за 20 та $40^{\circ} \mathrm{C}$ на бутилаті, метилаті та гідроксиді калію. Встановлено третій порядок формального кінетичного рівняння. Розраховано швидкості реакиії та уявні енергії активації. Останні виявилися майже рівними для бутилату та метилату (30 кДж/моль). Вивчено особливості утворення гліцеринового шару під час переетерифікації на бутилаті калію. Бутанольні розчини лужних каталізаторів досліджено методом ІЧ-спектроскопії. Зі зростанням концентрації бутилату калію спостерігалося виродження валентних коливань ОН-груп в області близько $3300 \mathrm{~cm}^{-1}$. Це може бути пов'язано з утворенням асоціатів між бутанолом та бутилатом калію. Проаналізовано принципові відмінності між реакційними стадіями метанолізу та бутанолізу, спричинені низьким ступенем дисоціації бутилату калію в малополярному бутанолі. Розглянуто шляхи утворення гліцерату калію та його значення в подальшому перебігу процесу.

Ключові слова: бутилові естери жирних кислот; бутилат калію; гідроксид калію; гліцерат калію; утворення алкоголятаніона.

\section{ALKALINE TRANSESTERIFICATION OF SUNFLOWER OIL TRIGLYCERIDES BY BUTANOL-1 OVER POTASSIUM HYDROXIDE AND ALKOXIDES CATALYSTS}

L.K. Patrylak *, S.O. Zubenko, S.V. Konovalov, V.A. Povazhnyi V.P. Kukhar Institute of Bioorganic Chemistry and Petrochemistry of the National Academy of Sciences of Ukraine, Kyiv, Ukraine

\section{* e-mail: lkpg@ukr.net}

Butyl esters of fatty acids are used in engineering and are considered as potential biodiesel fuel. The difficulty of separation of products, obtaining by alkaline transesterification of oils, causes the pure attention of researchers to this one-stage of synthesis of butyl esters. The difficulty of separating the products obtained by alkaline transesterification of vegetable oils leads to the limited attention of researchers to this one-step route of the synthesis of butyl esters. The aim of this work was to compare the characteristics of the alkaline transesterification of sunflower oil on hydroxide and water-free alkoxide catalysts and to interpret the observed features from the point of view of reaction mechanism. Transesterification was carried out at the temperature of 20 and $40^{\circ} \mathrm{C}$ using potassium butoxide, methoxide and hydroxide. The highest equilibrium yield of butyl esters (up to 96\%) was achieved when potassium butoxide was used, whereas it did not exceed $85 \%$ for the case of potassium hydroxide. The third order of reaction was determined. The reaction rate constants and apparent activation energies were calculated. The activation energies were found to be almost equal for both used alkoxides $\left(30.5 \mathrm{~kJ} \mathrm{~mol}^{-1}\right)$. The features of the formation of glycerol layer were studied; this layer appeared during transesterification using potassium butoxide. Alkaline solutions of catalysts in butanol were studied by IR-spectroscopy. The degeneracy of valence vibrations of $\mathrm{OH}$-groups in the region of about $3300 \mathrm{~cm}^{-1}$ was observed with as an increase in the potassium butoxide concentration. This may be due to the formation of associates of butanol and butoxide. The fundamental differences between reaction stages of methanolysis and butanolysis, caused by low dissociation degree of potassium butoxide in low polar butanol, were discussed. The ways of the formation of potassium glyceroxide and its role in the further course of the process were considered.

Keywords: butyl esters of fatty acids; potassium butoxide; potassium hydroxide; potassium glyceroxide; glycerol layer; alkoxide-anion formation.

\section{REFERENCES}

1. Xu H., Han L., Cao P., Guo M., Han J., Yu D., Talalay P. Low-molecular-weight, fatty-acid esters as potential lowtemperature drilling fluids for ice coring. Annals of Glaciology, 2014, vol. 55, pp. 39-43.

2. Shereshevskiy A.I., Unanyants T.P., Bakharovskiy G.Ya., Khimicheskie tovary: spravochnik, Chast' 1 [Chemical products: a handbook, part 1]. Gosudarstvennoe nauchno-tekhicheskoe izdatel'stvo khimicheskoi literatury Publishers, Moscow, 1961. 1090 p. (in Russian).

3. Bodachivskyi I., Pop G., Zheleznyi L., Zubenko S., Okhrimenko M. Oleochemical synthesis of sulfanes, their structure and properties. Chemistry \& Chemical Technology, 2017, vol. 11, pp. 365-371.

4. Patrylak L.K., Zubenko S.O., Konovalov S.V. Pereesteryfikatsiya ripakovoyi oiyi butanolom na luzhnykh katalizatorakh [Transesterification of rapeseed oil by butanol over alkaline catalysts]. Voprosy Khimii i Khimicheskoi Tekhnologii, 2018, no. 5, pp. 125-130. (in Ukrainian).

5. Zubenko S.O., Konovalov S.V., Patrylak L.K., Okhrimenko M.V. Preparation of potassium butylate with potassium hydroxide and n-butyl alcohol for using in trigliceride transesterification process. Kataliz i Neftekhimiya, 2017, no. 26, pp. 36-39.

6. Patrylak L.K., Okhrimenko M.V., Levterov A.M., Konovalov S.V., Yakovenko A.V., Zubenko S.O. Engine performance and emission of biodiesel fuel prepared from different Ukrainian natural oils. Chemical Papers, 2019, vol. 73, pp. 1823-1832.

7. Likozar B., Levec J. Transesterification of canola, palm, peanut, soybean and sunflower oil with methanol, ethanol, isopropanol, butanol and tert-butanol to biodiesel: Modelling of chemical equilibrium, reaction kinetics and mass transfer based on fatty acid composition. Applied Energy, 2014, vol. 123, pp. $108-120$.

8. Kozitsyna L.A., Kupletskaya N.B., Primenenie UF-. IK-, YaMR- $i$ mass-spektroskopii $v$ organicheskoy khimii [The use of UV, IR, NMR and mass spectroscopies in organic chemistry]. Moscow University Publishers, Moscow, 1979. 240 p. (in Russian).

9. Simonov A.P., Shigorin D.N. Infrakrasnye spektry pogloscheniya i stroenie tretichnogo butilata litiya [Infrared adsorption spectra and structure of tertiary lithium butoxide]. Optika i Spektroskopiya. 1957, pp. 244-249. (in Russian).

10. Pretsch E., Buhlmann P., Affolter C., Structure determination of organic compounds. Springer, New York, 2000. 433 p.

11. Lotero E., Liu Y., Lopez D.E., Suwannakarn K., Bruce D.A., Goodwin J.G. Synthesis of biodiesel via acid catalysis. Industrial \& Engineering Chemistry Research, 2005, vol. 44, pp. 5353-5363.

12. Guo F., Fang Z. Biodiesel production with solid catalysts. In: Biodiesel - Feedstocks and Processing Technologies, M. Stoytcheva, G. Montero (eds.). InTechOpen, New York, 2011, pp. 339-358. Available at: https://doi.org/10.5772/25602.

13. Boey P.-L., Maniam G.P., Hamid S.A. Performance of calcium oxide as a heterogeneous catalyst in biodiesel production: a review. Chemical Engineering Journal, 2011, vol. 168 , pp. 15-22.

14. Silverstein T.P., Heller S.T. $\mathrm{pK}_{\mathrm{a}}$ values in the undergraduate curriculum: what is the real $\mathrm{pK}_{\mathrm{a}}$ of water? Journal of Chemical Education, 2017, vol. 94, pp. 690-695.

15. Serjeant E.P., Dempsey B., Ionisation constants of organic acids in aqueous solution. IUPAC Chemical Data Series, 1979, no. 23, p. 989. 